\title{
The Response of Botanical Seeds of Trisula and Biru Lancor Shallot Varieties to Coconut Water Treatment
}

\author{
Tri Sudaryono \\ East Java Assessment Institute for Agricultural Technology, Malang, East Java, Indonesia
}

\begin{abstract}
The use of botanical seeds for seedling cultivation has problems related to the number of produced tubers, where in general botanical seeds on average only produce 1-2 tubers. Another problem with the cultivation of shallots with botanical seeds as a source of seedlings is the low growth of seeds (germination). To overcome the problems that exist in botanical seeds, growth regulators are used. This study aimed to determine the effect of coconut water treatment on the growth and yield of Trisula and Biru Lancor shallot varieties from botanical seeds, carried out from April to August 2018 in Pelem Village in Pare Sub-District, Kediri Regency. The utilized method is soaking the shallot botanical seeds for 4 hours before sowing; the seeds were then sown and planted for a month before being moved to the field. After growing in the field, observations were carried out at 1-week intervals on vegetative and generative growth. Sampling was random, and data was analyzed with t-test/LSD at a level of $5 \%$. The results showed that the botanical seeds of Trisula and Biru Lancor shallot varieties showed different responses to the treatment with young coconut water. The use of coconut water for the Trisula variety led to $70 \%$ of plants yielding more than six cloves, while the Biru Lancor variety only had $46.67 \%$. The use of coconut water for the Trisula variety yielded a fresh tuber weight of $71.2 \mathrm{~g}$ per plant at harvest; if converted per hectare, the Trisula variety can yield approximately 32 tons of fresh tubers. Meanwhile, the Biru Lancor variety yielded a tuber weight of $57.4 \mathrm{~g}$ per plant at harvest, and if converted per hectare, the Biru Lancor variety can yield approximately 26 tons of fresh tubers.
\end{abstract}

Keywords: Botanical seed, Coconut Water, Shallots

\section{INTRODUCTION}

Shallots are presently generally cultivated by using tubers as seedlings. There are disadvantages of using tubers as seedlings in shallot farming, one of which is that the cost of providing seed tubers is quite high, which is about $40 \%$ of the total production costs $[1,2]$. In addition, the health quality of seed tubers is not guaranteed because they almost always carry disease pathogens such as Fusarium sp. and Colletotrichum sp. fungi, viruses such as the Shallot Latent Virus (SLV) and Leek Yellow Stripe Virus (LYSV), as well as bacteria from their native plants which attack the plants, thus reducing yields $[3,4]$.

The weaknesses of vegetative propagation by tubers can be sidestepped through propagation by botanical seeds of shallots. Therefore, the use of botanical seeds is one alternative that can be developed to improve the quality of shallot seeds [5-8].

The use of botanical seeds compared to the use of seed tubers (the conventional method) has several advantages. The amount of botanical

*Correspondence address:

Tri Sudaryono

Email : tri_sdr@yahoo.com

Address : East Java Assessment Institute for Agricultural

Technology, Malang, East Java, Indonesia seed needs is less than 3-6 kg.ha-1 ${ }^{-1}$ while the requirement of seed tubers ranges from 1-1.5 tons.ha ${ }^{-1}$; botanical seeds are more accessible and cheaper in terms of storage and distribution, produce healthier plants because they are free of pathogens, and produce tubers of better quality $[9,10]$. In addition, the use of shallot seeds is economically feasible because it can increase yield by twofold compared to the conventional use of seed tubers [11]. Currently, the technology of producing botanical seeds of shallots has been developed, and there are relatively no problems, but the problem lies in the growth of botanical seeds. The use of botanical seeds for seedling cultivation has problems related to the number of produced tubers. Botanical seeds only produce 1-2 tubers on average [12]. The minimum number of produced tubers appears to be related to the small number of tillers produced by botanical seeds. The shallot tillers are the development of apical buds that form due to the loss of the dominance of the apical buds. The initiation of these shoots occurs after apical meristem cell division. The formation of seedlings of shallots from botanical seeds is still tricky to perform because tuber formation cannot be influenced by temperature, spacing, and water stress [13].

Another problem with the cultivation of shallots with botanical seeds as a source of 
seedlings is the low growth of seeds (germination). A growth regulator substance that is widely used in research on shallots is gibberellin (GA). The growth of shallot botanical seeds can be increased by immersion in a gibberellin solution before sowing. For three shallot varieties, the percentage of shallot seed sprouts was the best in seeds given an immersion treatment in gibberellin solution for 4 hours at the seedling age of 2 weeks [14]. The use of growth regulator substances combined with auxin, cytokinins, and gibberellins was able to increase the number of leaves, the number of tubers, and the fresh weight of plants [15]. The best and most efficient way of GA3 application for blooming, fertilizing, and yielding shallots is by soaking seed tubers for 30 minutes in a GA3 solution of 200 ppm [7].

Another substance that can be used as a growth regulator is coconut water. Coconut water not only contains vitamins and minerals [16], but also the growth hormones of auxin, cytokinins, and gibberellins in sufficient concentrations [17]. Coconut water contains the auxin hormone in the form of IAA with a level of approximately $0.237 \mathrm{ppm}$; cytokinin in the forms of kinetin with a concentration of $0.441 \mathrm{ppm}$ and zeatin with a concentration of $0.247 \mathrm{ppm}$; and gibberellins in the form of GA3, GA5, and GA7 with concentrations of $0.460 \mathrm{ppm}, 0.255 \mathrm{ppm}$, and $0.053 \mathrm{ppm}$ respectively [17]. Coconut water also contains minerals that function as nutrients, which are $\mathrm{N}, \mathrm{P}, \mathrm{K}, \mathrm{Mg}$, $\mathrm{Fe}, \mathrm{Na}$, and $\mathrm{Ca}[16,17]$.

Thus, young coconut water could be used as a growth regulator in shallot cultivation by using botanical seeds as a seed source. Treatment of coconut water on shallot botanical seeds of the Trisula variety and sowing on soil mixture + manure, soil mixture + husk charcoal, and soil mixture + compost + husk charcoal can increase sprout growth by $90 \%$ and optimize seed growth [18]. Shallot plants originating from botanical seeds that are treated with coconut water, in addition to having optimum plant growth, also yielded the highest number of tubers per plant and the highest tuber weights per plant [19]. The use of coconut water for the treatment of shallot botanical seeds will make it easier for farmers, considering that coconut water is easily obtained and inexpensive.

The aim of this study is to determine the effect of coconut water treatment on the growth and yield of Trisula and Biru Lancor shallot varieties grown from botanical seeds.

\section{METHODOLOGY}

The study was conducted at Pelem Village in Pare District, Kediri Regency, from April to August 2019. The study was performed using a randomized block design that was repeated ten times. Botanical seed nursery was carried out from April-May 2018. Before the seeds were sown, they were first soaked in a coconut water solution for 4 hours. This soaking process was for the botanical seeds to absorb the compounds in coconut water. Seed germination is a mechanism in which morphological and physiological alterations result in activation of the embryo. Before germination, seeds absorb water, resulting in the expansion and elongation of the seed embryo [20]. Next, the seeds were planted in a plastic bag containing a mixture of soil and compost media with a ratio of $1: 1$. The seeds were sown until the age of 1 month after seedling growth, and then the shallot seedlings were planted in the field.

Each shallot variety (Trisula and Biru Lancor) was planted in 10 beds measuring $5 \mathrm{~m} \times 4 \mathrm{~m}$. Shallot seeds were planted on beds with a spacing of $12.5 \mathrm{~cm} \times 15 \mathrm{~cm}$. Total of 10 plants were selected randomly as samples for observation of plant growth. Observation of vegetative growth (number of leaves, plant height) and generative growth (number of stems/tillers) was carried out at one-week intervals, while the observation of yield components (number of tubers, tuber weight per plant) was carried out at harvest. The variable analysis was carried out to determine the effect of coconut water treatment and continued with t-test/LSD at a level of $5 \%$.

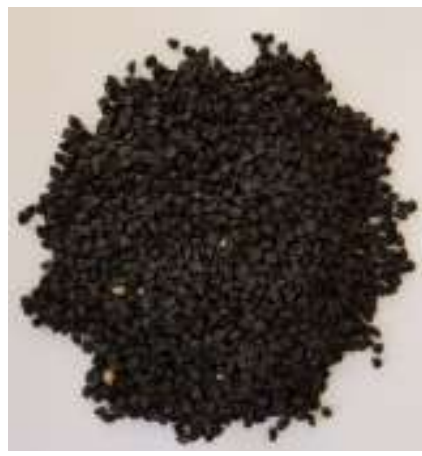

Figure 1. Shallot Botanical Seeds

\section{RESULTS AND DISCUSSION \\ Vegetative Growth}

The results of statistical analysis showed that the treatment of coconut water affected the vegetative growth of the Trisula and Biru Lancor varieties. The Trisula variety showed better 
growth in plant height, number of leaves, and number of stems compared to the Biru Lancor variety. The performance of vegetative growth (plant height, number of leaves, and number of stems) of the Trisula and Biru Lancor varieties are presented in Tables 1, 2, and 3, respectively.

Table 1. Plant height of the Trisula and Biru Lancor shallot varieties after transplanting

\begin{tabular}{lrrrr}
\hline \multirow{2}{*}{ Variety } & \multicolumn{4}{c}{ Plant Height (cm) } \\
\cline { 2 - 5 } & 2 WAT & 3 WAT & 4 WAT & 5 WAT \\
\hline Trisula & $32.18 \mathrm{a}$ & $37.22 \mathrm{a}$ & $46.03 \mathrm{a}$ & $51.82 \mathrm{a}$ \\
Biru Lancor & $28.73 \mathrm{~b}$ & $34.42 \mathrm{~b}$ & $41.28 \mathrm{~b}$ & $47.53 \mathrm{~b}$ \\
\hline
\end{tabular}

Notes: Numbers in the same column followed by different letters are significantly different based on the t-test with a level of $5 \%$. WAT: Weeks after Transplanting

Table 2. Number of leaves of Trisula and Biru Lancor shallot varieties after transplanting

\begin{tabular}{lllll}
\hline \multicolumn{1}{c}{ Variety } & \multicolumn{4}{c}{ Number of Leaves } \\
\cline { 2 - 5 } & 2 WAT & 3 WAT & 4 WAT & 5 WAT \\
\hline Trisula & $12.53 \mathrm{a}$ & $17.27 \mathrm{a}$ & $22.13 \mathrm{a}$ & $25.07 \mathrm{a}$ \\
Biru Lancor & $14.50 \mathrm{~b}$ & $15.30 \mathrm{~b}$ & $22.67 \mathrm{a}$ & $29.33 \mathrm{~b}$
\end{tabular}

Notes: Numbers in the same column followed by different letters are significantly different based on the t-test with a level of $5 \%$. WAT: Weeks after Transplanting

Table 3. Number of branches of the Trisula and Biru Lancor shallot varieties after transplanting

\begin{tabular}{lcccc}
\hline \multicolumn{1}{c}{ Variety } & \multicolumn{4}{c}{ Number of Branches } \\
& 2 WAT & 3 WAT & 4 WAT & 5 WAT \\
\hline Trisula & $3.13 \mathrm{a}$ & $4.33 \mathrm{a}$ & $5.53 \mathrm{a}$ & $6.27 \mathrm{a}$ \\
Biru & $2.90 \mathrm{a}$ & $3.17 \mathrm{~b}$ & $4.47 \mathrm{~b}$ & $5.87 \mathrm{a}$ \\
Lancor & & & &
\end{tabular}

Notes: Numbers in the same column followed by different letters are significantly different based on the t-test with a level of $5 \%$.

WAT: Weeks after Transplanting

Based on Tables 3, 4, and 5, the treatment of coconut water immersion resulted in good/optimal vegetative growth, although there were differences in vegetative growth between the Trisula and Biru Lancor varieties. Another research had shown that coconut water immersion influenced the growth of mustard plants, mainly on growth components of plant height and number of leaves [21]. In addition, another study had also shown that the application of coconut water increased the growth of in vitro ginger [22]. The coconut water is an endosperm liquid containing organic compounds, including auxin and cytokinin [23]. When immersed in a young coconut solution, botanical seed tissues absorb auxin and cytokinin, thereby increasing cell division, elongation, and differentiation of cells, which ultimately increases plant growth.

Plant growth is influenced by the availability and distribution of food in other parts of plants, the uptake of water or nutrients by parts of plants, the presence of growth regulators, or the formation of certain substances in plants [24]. Furthermore, the presence of auxin in plants not only spurs stem lengthening but also encourages the growth of all parts of plants, including roots and leaves [25]. In addition to containing the growth hormones of auxin, cytokinin, and gibberellin, coconut water also includes the nitrogen (N) nutrient. Nitrogen is needed by plants to encourage vegetative growth. Plants require nitrogen $(N)$ for vegetative growth of leaves, stems, and roots [26].

\section{Components of Generative Growth and Results}

At the age of 70 days after transplanting, the shallot plants are ready to be harvested, which is marked by $60 \%$ soft neck stems, yellow leaves, and fallen plants (Fig. 2). Statistical analysis showed that the treatment of immersion in coconut water for botanical seeds influenced the generative growth of shallots, including the number of tillers/stems, number of tubers per plant, tuber weight per plant, and yield/production.

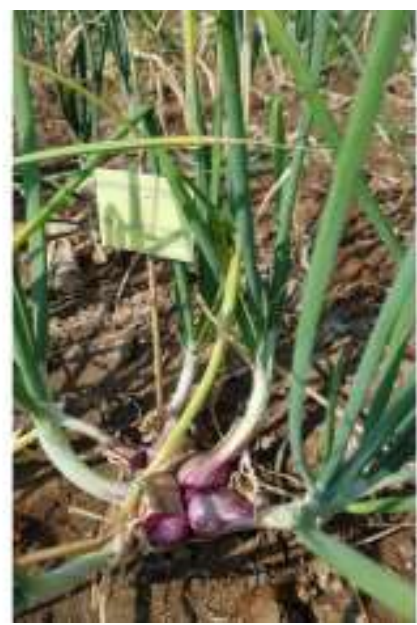

Figure 2. Shallot plants from botanical seeds that are ready to be harvested

At harvest, the Trisula shallot variety from botanical seeds showed greater generative performance (number of branches), yield components (tuber number per plant, tuber weight per plant), and yields, compared to the Biru Lancor variety from botanical seeds (Table 4).

The components of the Trisula variety of shallots from botanical seeds are better than the Biru Lancor variety, where the tuber weight per plant is greater. The greater tuber weight per plant seems to be related to the number of branches/tillers and the number of tubers per 
plant. Based on Table 4, there appears to be a correlation of the number of branches/tillers, the number of tubers per plant, and tuber weight per plant toward production.

Table 4. Generative and yield components of the Trisula and Biru Lancor shallot varieties from botanical seeds

\begin{tabular}{lcccc}
\hline & \multicolumn{4}{c}{ Generative and Yield Components } \\
\cline { 2 - 5 } Variety & $\begin{array}{c}\text { Number } \\
\text { of } \\
\text { Branches }\end{array}$ & $\begin{array}{c}\text { Number } \\
\text { of Tubers } \\
\text { per plant }\end{array}$ & $\begin{array}{c}\text { Tuber } \\
\text { Weight } \\
\text { per } \\
\text { plant } \\
\text { (g) }\end{array}$ & $\begin{array}{c}\text { Production } \\
\text { (tons.ha-1) }\end{array}$ \\
\hline Trisula & $6.8 \mathrm{a}$ & $7.3 \mathrm{a}$ & $71.2 \mathrm{a}$ & $32.0 \mathrm{a}$ \\
Biru Lancor & $6.0 \mathrm{a}$ & $6.5 \mathrm{a}$ & $57.4 \mathrm{~b}$ & $26.0 \mathrm{~b}$ \\
\hline
\end{tabular}

Notes: Numbers in the same column followed by different letters are significantly different based on the t-test with a level of $5 \%$.

The Trisula variety produces a greater number of branches/tillers, number of tubers per plant, and tuber weight per plant, and has higher production than the Biru Lancor variety. The Biru Lancor variety had a production of 26 tons.ha ${ }^{-1}$, less than the Trisula variety. The Trisula variety showed more branches/tillers and tubers per plant than the Biru Lancor variety (Fig. 3). Although the number of tubers per plant was lower than the Trisula variety, the Biru Lancor variety showed an average number of 6 tubers per plant. This fact indicates that coconut water can be used as a solution to the problem of low number of tubers produced by shallot plants from botanical seeds.

When examined further, $70 \%$ of the Trisula variety of shallot plants from botanical seeds produced more than 6 tubers per plant, while for the Biru Lancor variety, only $46.67 \%$ produced the same number of tubers. In detail, the percentages of plants with $4,5,6$, and more than 6 tubers, for both the Trisula and Biru Lancor varieties, are presented in Table 5.

Table 5 shows that the treatment of coconut water can increase the number of shallot tubers. The results of this study are in line with Rajiman [27] who reported that the provision of real coconut water affects the vegetative growth of shallot plants, especially the number of leaves, as well as their generative growth, namely the number of tubers, tuber diameter, and fresh and dry weight per clump. The provision of coconut water affected the number of shallot tubers [28]. Coconut water could increase the growth and production of shallots [29].

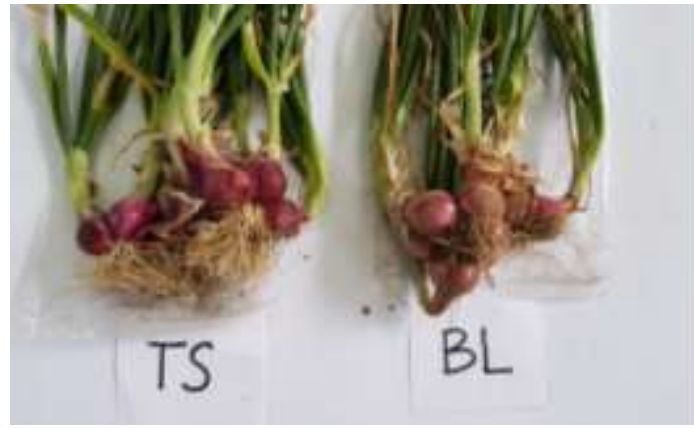

Figure 3. Performance of Trisula (TS) and Biru Lancor (BL) shallot varieties from botanical seeds

Table 5. Percentages of plants with 4, 5, 6, and more than 6 tubers of Trisula and Biru Lancor shallot varieties from botanical seeds

\begin{tabular}{lllll}
\hline \multirow{2}{*}{ Variety } & \multicolumn{4}{c}{ Percentage of tubers per plant (\%) } \\
\cline { 2 - 5 } & $\mathbf{4}$ tubers & $\mathbf{5}$ tubers & $\mathbf{6}$ tubers & $>\mathbf{6}$ tubers \\
\hline Trisula & $6.67 \mathrm{a}$ & $10.00 \mathrm{a}$ & $13.33 \mathrm{a}$ & $70.00 \mathrm{a}$ \\
Biru Lancor & $13.33 \mathrm{~b}$ & $20.00 \mathrm{~b}$ & $20.00 \mathrm{~b}$ & $46.67 \mathrm{~b}$
\end{tabular}

Notes: Numbers in the same column followed by different letters are significantly different based on the t-test with a level of $5 \%$.

\section{CONCLUSION}

Botanical seeds of the Trisula and Biru Lancor shallot varieties showed different responses to the treatment with young coconut water. The treatment of coconut water for the Trisula variety enabled $70 \%$ of plants to be capable of producing of 6 or more tubers, while for the Biru Lancor variety only enabled $46.67 \%$. Coconut water treatment for the Trisula variety can yield $71.2 \mathrm{~g}$ of fresh tuber weight per plant at harvest time, and if converted per hectare, the Trisula variety can yield up to 32 tons of fresh tubers. Meanwhile, the Biru Lancor variety can yield 57.4 $\mathrm{g}$ of fresh tuber weight per plant at harvest time; if converted per hectare, the Biru Lancor variety can yield up to 26 tons of fresh tubers.

\section{REFFERENCES}

[1] Suherman, R., R.S. Basuki. 1990. Strategi luas usahatani bawang merah (Allium cepa var. ascalonicum) di Jawa Bali. Tinjauan dari segi usahatani terendah. Buletin Penelitian Hortikultura. 18(3). 11-18.

[2] Sunarto, A.D.H. Totok, S. Lukas, Suwarto, F. Noor. 2004. Peningkatan bawang merah (Allium cepa L) Brebes tahap II. Research Report. Faculty of Agriculture. Jenderal Soedirman University. Purwokerto

[3] Permadi, A.H. 1993. Growing shallot from true seed. Research Result and Problem Onion Newsletter for the Tropic. NRI United Kingdom. 5. 35-38.

[4] Arisuryanti, T., B.S. Daryono, S. Hartono. 2009. Pengembangan metode skrining 
ketahanan tanaman bawang merah (Allium ascalonicum L) terhadap virus menggunakan RT-PCR. Research Report. Faculty of Biology. Gadjah Mada University. Yogyakarta.

[5] Permadi, A.H. 1991. Penelitian pendahuluan variasi sifat-sifat bawang merah yang berasal dari biji. Buletin Penelitian Hortikultura. 2(4). 120-131

[6] Raduica, D.P. 2008. Research as the biology, technology and use of shallot (Allium ascalonicum). Hort. Magazine. 8. 250-257.

[7] Sumarni, N., E. Sumiati, Suwandi. 2005. Pengaruh kerapatan tanaman dan aplikasi zat pengatur tumbuh terhadap produksi umbi bibit bawang merah asal biji kultivar Bima. J. Hort. 15(3). 208-214.

[8] Sopha, G.A. 2010. Teknik persemaian true shallot seed (TSS). Research Center for Vegetables Plants. Lembang.

[9] Ridwan, H., H. Sutapraja, Margono. 1989. Daya produksi dan harga pokok benih/biji bawang merah. Buletin Penelitian Hortikultura. 17(4). 57-61.

[10] Rosliani, R., Suwandi, N. Sumarni. 2005. Pengaruh waktu tanam dan zat pengatur tumbuh mepiquat klorida terhadap pembungaan dan produksi biji bawang merah (TSS). J. Hort. 15(3). 192-198.

[11] Basuki, R.S. 2009. Analisis kelayakan teknis dan ekonomis teknologi budidaya bawang merah dengan biji botani dan benih umbi tradisional. J. Hort. 19(2). 214-227.

[12] Putrasamedja, S. 1995. Pengaruh jarak tanam terhadap pembentukan anakan pada kultivar bawang merah. Buletin Penelitian Hortikultura. 27(4). 87-92.

[13] Abbey, L., R. Fordham. 1997. Growth and yield sensitivity of pre-bulbing and bulbing shallots to water-strees. Crop Res. 14. 307313.

[14] Wulandari, A., D. Purnomo, Supriyono. 2014. Potensi biji botani bawang merah (True Shallot Seed) sebagai bahan tanam budidaya bawang merah di Indonesia. ElVivo. 2(1). 28-36.

[15] Irfan, M. 2013. Respon bawang merah (Allium ascalonicum L) terhadap zat pengatur tumbuh dan unsur hara. Jurnal Agroteknologi. 3(2). 35-40.

[16] Kristina, N.N., S.F. Syahid. 2012. Pengaruh air kelapa terhadap multiplikasi tunas in vitro, produksi rimpang, dan kandungan xanthorrhizol temu lawak di lapangan.
Jurnal Penelitian Tanaman Industri. 18(3). 125-134 .

[17] Djumhari, E. 2011. Pemanfaatan air kelapa untuk meningkatkan pertumbuhan stek pucuk meranti tembaga (Shorea leprosula Miq.). Jurnal Silvikultur Tropika. 2(1). 5-8.

[18] Sudaryono, T., P.E.R. Prahardini, F.N. Aziz, A. Suryadi, E. Retnaningtyas, Abu. 2017. Modifikasi media tumbuh dan pemberian zat pengatur tumbuh pada biji botani untuk menghasilkan umbi bawang merah. Final Research Report. BPTP of East Java. Malang.

[19] Sudaryono, T. 2018. Effect of plant growth regulator on red onion cultivation from true seed shallot. Indonesian J. Environ. Sustain. Dev. 9(1). 21-26.

[20] Miransari, M., D.L. Smith. 2014. Plant Hormones and Seed Germination. J. Env. Exp. Bot. 99. 110-121.

[21] Tiwery, R.R. 2014. Pengaruh penggunaan air kelapa (Cocos nucifera) terhadap pertumbuh-an tanaman sawi (Brassica juncea L.). Biopendix. 1(1). 83-91.

[22] Seswita, D. 2010. Penggunaan air kelapa sebagai zat pengatur tumbuh pada multiplikasi tunas temu lawak (Curcuma xanthorrihiza Roxb.) in vitro. Jurnal Penelitian Tanaman Industri. 16(4). 135140.

[23] Budiono, D.P. 2004. Multiplikasi in vitro tunas bawang merah (Allium ascalonicum $\mathrm{L}$ ) pada berbagai taraf konsentrasi air kelapa. Jurnal Agronomi. 8(2). 75-80.

[24] Darmawan, J., J.S. Bahrsyah. 2010. Dasardasar fisiologi tanaman. SITC. Jakarta.

[25] Campbell. 2003. Biology. Erlangga. Jakarta.

[26] Prihmantoro, H. 1999. Memupuk tanaman buah. Penebar Swadaya. Jakarta.

[27] Rajiman. 2015. Pengaruh limbah air kelapa terhadap pertumbuhan dan hasil tiga varietas bawang merah. Jurnal Teknologi. 1. 15-31.

[28] Sembiring, B.E., Mariati, L. Mawarti. 2017. Pertumbuhan dan produksi bawang merah varietas Samosir (Allium ascalonicum L) pada beberap konsentrasi air kelapa dan lama perendaman. Jurnal Agroteknologi. 5(4). 780-785.

[29] Nana, S., S. Zochrotus. 2014. Pertumbuhan tanaman bawang merah (Allium cepa L) dengan penyiraman air kelapa (Coco nucifera L) sebagai sumber belajar Biologi SMA Kelas XII. Faculty of Mathematics and Natural Sciences. Ahmad Dahlan University. Yogyakarta. 